\title{
CHANGING REPRESENTATIONS OF INTIMATE PARTNER FEMICIDES BY A PORTUGUESE NEWSPAPER (2006 AND 2014): FROM EPISODIC TO THEMATIC FRAMES
}

\author{
Carolina Magalhães-Dias* and Soraia Lobo
}

\begin{abstract}
The media is one of the main vehicles for the dissemination of information and one of the primary means through which the social construction of intimate partner violence and femicide is made. In this study, content analysis was used to examine the portrayal of intimate partner femicide by news articles published in a Portuguese generalist daily newspaper. From a collection of 31 news articles published in 2014 and 24 in 2006, we found not only elements of episodic coverage, presenting the femicide as an isolated act, but also elements of thematic coverage, portraying the crime as an instance of a broader social problem.
\end{abstract}

Palavras-chave: Femicide, intimate partner violence, episodic and thematic frames, Portuguese press.

\section{Resumo}

Mudanças nas representações dos femicídios nas relações de intimidade por um jornal português (2006 e 2014): da cobertura episódica à cobertura temática.

Os meios de comunicação social são um dos principais veículos de disseminação da informação e um dos meios através dos quais é feita a construção social de diversas problemáticas, incluindo a violência e o femicídio nas relações de intimidade. Neste estudo foi feita uma análise de conteúdo à representação dos femicídios nas relações de intimidade pelas notícias publicadas num jornal diário generalista português. A partir de um corpus de análise constituído por 31 notícias publicadas em 2014 e 24 em 2006, foram encontrados não só elementos de cobertura episódica, apresentando o femicídio como um ato isolado, mas também elementos de cobertura temática, representando o crime como uma instância de um problema social mais amplo.

Palavras-chave: Femicídio, violência nas relações de intimidade, cobertura episódica e temática, imprensa portuguesa.

\section{Resumen}

Cambios en las representaciones de los feminicidios en las relaciones de pareja en un periódico portugués (2006 y 2014): desde la cobertura episódica para la cobertura temática.

Los medios de comunicación social son uno de los principales vehículos de difusión de información; además, a través de ellos se lleva a cabo la construcción social de diversos

\footnotetext{
* Faculdade de Direito, Universidade do Porto, 4050-123 Porto, Portugal. Endereço eletrónico: carolinajdias@gmail.com Endereço postal: Rua de Campo Lindo, n. ${ }^{\circ} 331$, 1. $^{\circ}$ Esq., 4200-147 Porto.

** Faculdade de Direito, Universidade do Porto, 4050-123 Porto, Portugal.

E-mail: soraia.o.lob@gmail.com
} 
problemas, incluida la violencia y lo feminicidio en las relaciones de pareja. En este estudio se realizó un análisis de contenido acerca de la representación de los feminicidios dentro de las relaciones de pareja en las noticias de un periódico diario portugués de carácter general. A partir de una colección de 31 noticias publicadas en 2014 y 24 en 2006, se hallaron tanto elementos de cobertura episódica, presentando el feminicidio como acto aislado, como también elementos de cobertura temática, representándolo como manifestación de un amplio problema social.

Palabras clave: Femicidio, violencia contra las mujeres en la pareja, cobertura episódica y temática, prensa portuguesa.

\section{Introduction}

Intimate partner violence (IPV) against women is a serious public health issue (Mahoney et al. 2001; Garcia-Moreno et al. 2006). However, only recently, and through the efforts of the feminist movement, has the issue started to be recognized as a human rights violation worthy of public, legislative and media attention (López Diéz 2002; Azambuja and Nogueira 2010).

Femicide, defined by Diana Russel (1992) as the misogynist killing of women by men, is a concept that is now starting to take its first steps in Portugal. This study examines the journalistic coverage of femicide in Portugal, but the term «femicide» has not been adopted by journalists, who talk about «murders» and «homicides». Regardless, in this article we draw on a feminist and gender perspective and will be using the term because it better expresses the analyzed phenomenon.

The issue of media representations has gained significant attention in recent decades as we have come to realize that they may affect the public's perception of social reality and who has power in that reality (Scheufele 1999; Reese 2001; Matheson 2005). In fact, as early as the 1960's, the feminist movement already understood the power the media have as producers of representations and practices that define women, gender, and violence (Cerqueira 2008).

As stated by Berns, the media are «public arenas where images of domestic violence are constructed, debated and reproduced» $(2001,263)$. This construction is made through the different types of coverage of IPV and intimate partner femicide (IPF) cases, namely thematic and episodic coverage. A thematic coverage frames the crime as part of a social issue and contextualizes the IPF as involving a pattern of IPV, while an episodic coverage presents the crime as an isolated event, "out of the blue», or motivated by a single, simple and/or individual cause (Bullock and Cubert 2002; Bullock 2008; Carlyle et al. 2008; Beddoe 2013; Fairbairn and Dawson 2013; Gillespie et al. 2013; Richards et al. 2013; Wozniak and McCloskey 2010).

Most extant research has demonstrated that newspaper articles reporting IPV and IPF predominantly present an episodic coverage, instead of framing the crime as part of a social problem that requires social solutions (Bullock and 
Cubert 2002; Bullock 2008; Carlyle et al. 2008; Wozniak and McCloskey 2010; Richards et al. 2011; Fairbairn and Dawson 2013; Gillespie et al. 2013; Richards et al. 2013). However, most studies focus on American newspaper articles, namely from the United States of America (Bullock and Cubert 2002; Bullock 2008; Carlyle et al. 2008; Wozniak and McCloskey 2010; Richards et al. 2011; Gillespie et al. 2013; Richards et al. 2013), Canada (Fairbairn and Dawson 2013) and Argentina (Angélico et al. 2014; Valdemarca and Bonavitta 2011). An example closer to us is a study from Spain that focused on another type of media, specifically television (Comas-d'Argemir 2014). In turn, studies that analyze the Portuguese press have mainly focused on other issues, such as the media representations of women (e.g., Cerqueira 2008).

The goal of this study is to expand the knowledge on the media's representation of femicide and its impact on the construction of IPV against women as a social problem. It attempts to provide a contribution to the analysis of the Portuguese journalistic coverage of gender violence in the form of IPF and compare it to the results gathered from similar studies conducted in other countries. First, a brief review of the literature on the most relevant issues surrounding the theme of this study will be offered. Second, the research questions and method used for the analysis will be explained. Next, the most relevant results will be presented and subsequently discussed. Lastly, limitations of this study and final considerations will be addressed.

\section{Review of the Literature}

As the focus of this study is on the journalistic coverage of femicide cases in Portugal, in this section we will first present the most relevant research and data on IPV and IPF at the international level and specifically in the Portuguese context. Data on the prevalence of IPV and IPF in Portugal will focus on the chosen years for the analysis, namely 2006 and 2014. Second, we will give a brief overview of the literature on media frames and their role in the construction of social problems such as gender violence and femicide. Lastly, the third part will present an overview of the studies that specifically analyzed the journalistic coverage of IPV and IPF.

Even after decades of research and advocacy, violence against women (VAW) continues in epidemic proportions, affecting women of all ages, ethnicities, cultures, and sexual orientations (Mahoney et al. 2001; Garcia-Moreno et al. 2006). Moreover, women are at higher risk of suffering violence by an intimate partner than by any other kind of perpetrator (Dobash and Dobash 2001; Mahoney et al. 2001; Garcia-Moreno et al. 2006). The 2015 summary report on the 20 years of the Beijing Declaration and Platform for Action states that almost half of female homicide victims are killed by their intimate partner or family members, making IPF one of the main causes of death for women. 
In Portugal, domestic violence (DV), which includes IPV, only began to be identified as a social problem in the 1980's (Coimbra 2007). The first legislation specifically focused on the protection of DV victims, the National Plan against Domestic Violence, created in 1999 and covering the years 2000 to 2003, has consistently been renovated and is currently in its $5^{\text {th }}$ edition. In parallel, the National Plan for Gender Equality, Citizenship and Non-Discrimination, likewise in its $5^{\text {th }}$ edition, promotes the implementation of measures to monitor media contents in order to identify sexist and stereotypical messages.

According to the RASI (Annual Report of Domestic Security), in the year 2014 there were 25 homicide victims murdered by an intimate partner in Portugal, and in all cases the victim was female and the perpetrator male. It should be noted that this Report considered solely the cases confirmed by the Criminal Police, and merely homicides in the context of a current relationship. Alternatively, the OMA (Observatory for Murdered Women) of UMAR (Women's Association Alternative and Response), in its 2014 Annual Report, announces 35 women murdered by their male intimate partners, collecting the data from news reports of several Portuguese newspapers, and also including past relationships. The same Observatory, in its 2006 Annual Report, mentions 32 women whose life was reaped by their current or past intimate partner.

It is through the media that we draw our comprehension of what happens outside our immediate circle of personal interaction (Reese 2001; Gallego Ayala 2003; Thornborrow 2004; Beddoe 2013). However, it is almost unanimous that news articles are not exact mirrors of reality that merely inform about an event (Cerqueira 2008; Angélico et al. 2014). There is always a construction of the covered event that may contribute to making different social issues more visible or, on the other hand, more invisible (Scheufele 1999; Cerqueira 2008; Angélico et al. 2014). This means that the journalistic tendency to systematically broadcast certain representations of social phenomena may result in the dissemination of those representations as predominant, establishing them as «common sense» (Scheufelle 1999; Bullock and Cubert 2002; Thornborrow 2004; Matheson 2005; Coimbra 2007). Therefore, news articles covering issues such as IPV may proliferate myths and offer overly simplistic, inadequate and distorted images of the extent and nature of the problem (Gillespie et al. 2013; Sutherland et al. 2016).

Media framing is particularly important in influencing public opinion on social problems (Beddoe 2013; Sutherland et al. 2016). It becomes thus necessary to present the concept of framing, which is said to have been introduced by sociologist Erving Goffman (1974). In his view, frames allow users to «locate, perceive, identify, and label a seemingly infinite number of concrete occurrences defined in its limits» (Goffman 1974, 21). There are thus multiple frames, and the media can choose which ones are predominant (Goffman 1974).

In Gitlin's (1980) perspective, on the other hand, frames are patterns of not only selection and exclusion of information, but also interpretation, emphasis, and presentation. Frames are, therefore, a part of a wider set of structures or soci- 
etal ideologies that actively generate information and organize discourses about the world (Gitlin 1980). Drawing on these and other views, Reese offers an overarching definition of frames as «organizing principles that are socially shared and persistent over time, that work symbolically to meaningfully structure the social world» $(2001,5)$.

Works on journalistic coverage of social issues have come to divide it in two types, namely episodic and thematic coverage (Scheufele 1999; Reese 2001; Beddoe 2013). Episodic reporting is most frequent and frames the particular incident and related responsibility in individual terms. Contrariwise, thematic frames are rarer and tend to present the event with reference to wider issues, including elements of the social context of the crime and broader social responsibilities (Scheufele 1999; Reese 2001; Beddoe 2013).

Sutherland and colleagues (2016) examined the guidelines developed by several countries to encourage responsible and ethical reporting of VAW. According to these guidelines and recommendations of other authors in this field (López Diéz 2002; Lledó Cunill 2003; Richards et al. 2014), the coverage of VAW must use thematic frames to present the crime as a social problem. That is, journalistic coverage should present statistics about the prevalence, incidence, and reporting rates of the problem; use terminology to identify the violence as a crime that violates human rights and not just another murder; contextualize the incident reported in a continuum of violence; highlight the lack of legal protection of women that denounce IPV; make an effort to quote and give voice to experts and advocates in the area; and provide resources available to women, such as crisis and support helplines.

This means that journalistic coverage should not use episodic frames to present the crime as an isolated case. That is, coverage of VAW should not represent the perpetrator as a madman, a monster or a psychopath, implying that men's use of violence is done only by mentally disturbed individuals; attribute as a main cause for the crime an isolated factor; use expressions that imply mutuality in the abuse; promulgate myths or misconceptions about IPV against women; present the IPV or IPF as a «crime of passion»; and ignore the existence and meaningful impacts of psychological violence (López Diéz 2002; Lledó Cunill 2003; Richards et al. 2014; Sutherland et al. 2016).

Equally, journalistic coverage of VAW must not contain elements of victim blaming, such as representing the victim as responsible for the aggression (López Diéz 2002; Richards et al. 2014; Sutherland et al. 2016), asking what she has done to provoke or cause the violence (López Diéz 2002) or inadvertently blaming her by referencing her behavior prior to, during, or after the violence (Sutherland et al. 2016). Likewise, it must also not present justifications for the perpetrator by stating he was too «in love» or «jealous» or in any other way that could be interpreted to excuse his behavior (López Diéz 2002) or by focusing on his positive characteristics, mitigating his accountability for the crime (Richards et al. 2014).

Previous studies about the journalistic portrayals of IPV (Berns 2001; Car- 
lyle et al. 2008;), intimate partner homicide (Bullock and Cubert 2002; Bullock 2008; Wozniak and McCloskey 2010; Fairbairn and Dawson 2013), IPF (Richards et al. 2011; Gillespie et al. 2013; Comas-d'Argemir 2014), and intimate partner femicide-suicide (Richards et al. 2013; Richards et al. 2014) have focused on at least some of the aforementioned thematic and episodic frames.

These studies have come to the conclusion that thematic frames, such as the reference to other cases of IPV or IPF; the mention of its rates or tendencies; the adequate description of its dynamics and social and psychological impacts; the indication of available resources to victims; and the contextualization of the particular event as involving IPV, either through the use of specific terms or the depiction of a previous pattern of abuse by the perpetrator against the victim, are rarely used (Bullock and Cubert 2002; Bullock 2008; Carlyle et al. 2008; Wozniak and McCloskey 2010; Richards et al. 2011; Fairbairn and Dawson 2013; Gillespie et al. 2013; Richards et al. 2013; Sutherland et al. 2016). Elements of victim blaming (Berns 2001; Bullock and Cubert 2002; Richards et al. 2011; Fairbairn and Dawson 2013) and perpetrator justification (Bullock and Cubert 2002; Fairbairn and Dawson 2013) have also been found. Though most news articles don't present a merely thematic or merely episodic coverage, containing instead both types of frames (Carlyle et al. 2008), episodic frames seem to be much more common (Carlyle et al. 2008; Wozniak and McCloskey 2010; Richards et al. 2011; Gillespie et al. 2013; Richards et al. 2013; 2014; Sutherland et al. 2016).

\section{The present study}

Based on the aforementioned literature, the following research questions were formulated to guide the analysis:

Research Question 1: Which frames of either form of coverage, thematic or episodic, are used to portray IPV or femicides in Portuguese newspaper articles about IPF?

Research Question 2: What similarities and differences relative to the use of thematic or episodic frames can be found in the coverage of IPF published in 2006 and 2014?

\subsection{Method}

The present study focused on the analysis of the journalistic coverage of cases of IPF, published in 2006 and 2014 in a daily generalist Portuguese newspaper, Jornal de Notícias (JN). This newspaper was chosen as it is one of the most influent newspapers in the North of Portugal (Simões 2011). The year 2006 was selected as it was the earliest year available for consultation of the authors, since the goal was to understand the differences between two sufficiently distant years. The year 2014 was chosen due to being the most recent year at the start of the study's planification. 
News items such as editorials, opinion articles, comments and interviews were excluded from analysis, as well as the news coverage of sequent events regarding the femicide case (e. g., coverage of the trial process). News articles for the year 2006 were collected through contact with the Municipal Library of Porto. News articles for the year 2014 were collected through contact with the OMA UMAR. In total, 24 textual items published in 2006 and 31 published in 2014 by JN were analyzed.

There are many methods to analyze newspaper articles. One such is critical discourse analysis, which follows the concept of discourse developed by Foucault (1972), from which several perspectives arose, especially in post-structuralist and post-modernist perspectives (Graham 2005). However, several authors have been developing an epistemological approach to the content of the text, providing a wide range of content analyses, such as quantitative or qualitative, inductive or deductive, manually or with a specialized software, and focusing on manifest and/or latent content (Elo and Kyngäs 2008). For this study we have used qualitative semi-inductive content analysis, done manually by both authors, and focusing on both manifest and latent content. The images featured in the news articles were not a target of analysis.

The analysis began with an extensive and repeated reading of all news articles, for better immersion in the cases and situations covered. An initial inductive analysis was performed, to gather ideas that emerged from the texts. As suggested by Elo and Kyngäs (2008), an unconstrained categorization matrix was then constructed, following the aforementioned extant research and literature. The ideas emergent from the inductive analysis were then organized in categories, which were later redefined and reformulated in relation to the categorization matrix, that grouped categories and subcategories in two main themes, namely elements of thematic coverage and elements of episodic coverage.

\section{Main Results}

Below we present the main results we drew from the analysis, grouped in the two major themes, thematic and episodic frames. Each theme is divided in categories that represent the different frames that emerged from the analysis.

\subsection{Thematic Frames}

\section{Domestic violence and intimate partner femicide as social problems}

In both years, journalists used elements to contextualize DV as a social issue, such as statistical data and the mention of previously reported DV cases. In 2014, these references were present in almost a third of the articles, frequently in separate sections of the main text, and using succinct and fact-centered language. 
Conversely, in the year 2006, these references were extremely rare and emerged in separate boxes and one subhead.

560 weapons were apprehended by GNR [police force], last year, in a context of domestic violence; $26.7 \%$ more apprehended weapons than in 2012. (14.05.08-A)

The dark scenario is shown by the numbers of murders registered by JN: $18(72 \%)$ of the 25 homicides committed since the beginning of the year happened in a family context. (14.05.08-A)

Elements of connection to a social problem, however, weren't limited to the broader issue of DV or homicides in a family context. In fact, the present study found that journalists from JN used elements to specifically construct IPF as a social issue in their news articles from both years, by revealing recent numbers on the phenomenon.

50 women were killed by their partners in the last two years. Additionally, the authorities registered 37 attempted homicides. (06.09.08-A)

Social drama. 28 women killed this year by their partners. (14.10.28-A)

Moreover, in one news item from 2014, a similar case was mentioned in the main text, due to the spatial and temporal proximity between the crimes:

«Can you believe it? It's the second case in Póvoa do Varzim [locality] in four days!» claimed another neighbor, remembering the woman that, last Saturday afternoon, was shot in the head by her ex-partner. (14.12.04-A)

In the year 2014 we found no references to the resources available to victims. In 2006, despite the use of an association (APAV - Portuguese Association of Victim Support) as a source about DV rates in one news item, it was not presented as an available resource, as no information useful to victims was mentioned (such as, for example, contact information).

3537 domestic violence complaints were presented in the first trimester of this year, according to the Portuguese Association of Victim Support. (06.09.08-A)

\section{The femicide as part of a history of IPV}

In most news articles, the crime was portrayed as the final step in a long history of IPV by the perpetrator against the victim. This was done by detailing previous episodes of violence, mentioning charges of DV pressed by the victim, and revealing the fear felt by the victim. One of the main similarities found in both 
years was the overwhelming representation of previous episodes of physical violence. On the other hand, mentions of psychological violence were made in 2006 exclusively in the form of threats made by the perpetrator. In 2014, references were also made to other forms of psychological violence, such as humiliations and other controlling strategies by the perpetrator, better portraying the different forms of violence.

According to neighbors [...] «He beat her a lot» [...] Which was confirmed by the GNR, that had received several complaints of assaults committed by the man toward the woman. (06.12.08-A)

«She lived in permanent terror, because he was wicked», told a neighbor, that witnessed several arguments between the couple and at least one assault. (14.10.28-A)

The murder of lawyer Ana Rita Antunes was the culmination of months of threats and humiliations. (14.11.22-A)

\section{Criticizing the justice system}

The media hold a fundamental role to reveal that society, predominantly when it comes to the justice system, could have taken steps to prevent these femicides. In some news items from both years we found the frame that the femicide occurred because the justice system was not capable of preventing it, due to its inadequate response to DV.

In July, he was arrested by the PJ [police agency] for shooting a nephew of his expartner, for suspecting that they were maintaining a romantic relationship. He was presented to the Vila Franca [locality] Court, but left with only a conditional bail. (06.09.08-B, emphasis added)

«Shocked» with the death of her neighbor, clamors a «heavier hand [of justice] (sic) for domestic violence» (...) (14.12.04-A)

[After the victim pressed charges] The authorities started investigating but weren't in time to prevent the worse. (14.10.28-A)

\subsection{Episodic Frames}

The femicide as an isolated event

Despite the aforementioned promising results, some ideas that emerged from the analysis align with what previous literature has revealed about the frame of IPF as an isolated act (Richards et al. 2011; among others). Some news articles from both years presented the couple as having a normal and stable rela- 
tionship, where no violence was known. The crime is portrayed as either happening "out of the blue», leaving the community of friends, relatives and neighbors in shock, or due to vague problems in the couples' lives.

Family and friends are in shock. They guarantee that nothing could have predicted such a tragic ending. (06.04.11-A)

There's talk of problems between the couple, presumably economic. (14.08.31-A)

\section{Violence as mutual between the couple}

On the other hand, some news articles from both years, despite mentioning the existence of problems or violence in the relationship, present it as ambivalent or mutual between the couple, without identifying a perpetrator. These assertions assign the femicide to conflicts and complications in the relationship, not representing it as gender violence. By ignoring the context of coercive control in the portrayal of IPF, the crime appears irrational and we are left with the impression that both parts equally contributed to the violence.

The couple was already known by their constant fights, the result, as neighbors state, of difficult tempers. (06.04.20-A)

The family environment, that José [neighbor] had once considered the "portrait of happiness», had lately been restless due to arguments between the couple. $(14.10 .21-\mathrm{A})$

\section{Victim blaming}

As found by others (Fairbairn and Dawson 2013; among others), some elements of victim blaming also emerged, in both years. By portraying the victim as behaving reprehensibly or as having failed to take adequate measures to stop or prevent the violence, it is implied that it is the victim's obligation and responsibility to leave the relationship or end the violence, and that, if she had acted differently, she would not have been murdered.

The man stated that the woman got drunk on a daily basis. (06.08.29-A)

Manuela never took it [threats] seriously and said that it was nothing, having never pressed charges to the authorities. (14.01.13-B)

He [perpetrator] even asked to borrow a mattress from her, to sleep in the building's attic, and, once again, she caved. (14.05.08-A, emphasis added) 


\section{Justifying the perpetrator's crime}

As prior studies have mentioned (for instance, Bullock and Cubert 2002), some Portuguese news articles from JN in both years also presented frames that convey attempts to justify the perpetrator's actions. Whether by drawing conclusions about his intentions to kill or by the significance given to his mental problems, the violence was portrayed as accidental or caused by mental disorders outside of the perpetrator's control. In one case, the femicide was even framed as an act of mercy.

The day before last, moved by the despair of watching his wife languishing every day, he decided to end the suffering of both. (06.06.01-A)

Sources close to the couple assured that he had no intention to kill his wife and that it had all been just an unfortunate «fatality». (14.05.31-A)

According to a source that knows the couple, in the last year [the perpetrator] had been suffering from mental disorders, which had already earned him a psychiatric internment. (14.04.14-A)

\section{$I P V$ as a private problem of the couple}

Some news items published in 2014 contained the evocation of one of the most damaging myths about DV, the idea that problems in the relationship are to be solved between husband and wife, without interference from outsiders.

«Sometimes we could hear the arguments, but people don't care because it's the couple's problem», a neighbor stated. (14.02.04-A)

The closest neighbors contacted by JN claimed to have no knowledge of other episodes of violence, admitting only that they had noticed some arguments. «He used to yell a lot, but I can't say he hit her, because I don't know what was happening inside the house». (14.07.11-A)

The latter example also demonstrates the devaluation of psychological violence. Despite the source identifying «him» as the person that yells, conveying the perpetrator-victim dichotomy, the quote portrays that «at least» no physical violence was known, and therefore it isn't considered violence at all.

\section{Femicide due to the perpetrator's feeling of loss of property over the victim}

When not identifying the femicide as part of IPV, news articles from both years centered their search for causes around the typical ideology of jealousy, 
which some authors have named the «male sexual proprietariness» (Wilson and Daly 1993, 1). The main motives presented by journalists for the femicides, in news articles that failed to denounce the previous pattern of abuse in the relationship, were the aggressor's feelings of jealousy, the victim's desire or actions to end the relationship, and the perpetrator's unacceptance of an already terminated relationship, representing the crime as the often called «act of passion».

The reason behind the shooting could be the man's resentment for having been replaced by another. (06.11.04-A)

An act that might have been committed due to jealousy and suspicions that his wife was cheating on him. (06.09.26-A)

According to another closer friend, who had spoken to Luana the previous night, the dentist [victim] said she had asked for divorce to her husband, something that Marcos hadn't taken well. (14.05.29-A)

\section{Discussion}

This study shows that, despite most studies on the journalistic portrayal of IPV and IPF concluding that an extremely small minority of news articles names DV as a social issue (Wozniak and McCloskey 2010; among others), a different picture was fortunately painted when it came to the present analysis of the Portuguese newspaper JN. In fact, more than half of the news items used elements that connected the covered femicide case with a broader social problem. Presenting other recent and/or similar cases of DV or specifically IPF and referencing the rates or tendencies concerning these crimes may help readers make the connection between these crimes and the broader issue that affects society at large. The contextualization of the crime as part of a previous pattern of IPV, in conjunction with the criticism of the justice system for not having been able to prevent the tragedy, also contributes to a greater awareness of the role of society in stopping this type of crime. Unfortunately, contrary to findings from other studies (Gillespie et al. 2013; among others), no news item mentioned resources available to victims.

On the other hand, episodic frames were also found, reinforcing what was the traditional role of the media, namely the non-recognition of this social problem, the characterization of the femicide as an isolated event that «came from nowhere» or was a result of mutual conflicts in the relationship. The «search for causes» without considering the dynamics of DV may root in its audience a system of beliefs in which IPV is seen as a result of high levels of stress in a relationship and, therefore, inevitable (Fairbairn and Dawson 2013). When explanations like these are presented as adequate to rationalize such a hideous act, the impe- 
tus is lost to consider deeper issues such as society's role in perpetuating or breaking the cycle. Moreover, it is essential to deconstruct the myth that jealousy is romantic, to prevent the acceptance of some of the most common strategies of control employed by IPV perpetrators, such as the evocation of their jealousy to isolate victims from their support groups.

It is worth noting that in 2014 thematic frames were more common and episodic frames less common than in 2006. However, the presence of episodic frames, even if rare, highlights a patriarchal discourse of blaming the victim and justifying the perpetrator's actions and the idea that DV is a private problem that needs to be resolved by the family, denouncing ignorance about IPV. This could be prevented with a closer work between journalists and DV experts and advocates, which could not only improve the coverage of IPF by providing contextual information from a thematic or societal perspective, but also benefit IPV victims that may be compelled to seek help by reading about these tragedies.

This seems to be the case in Spain, more specifically in the Autonomous Region of Cataluña, where a manual of Recomanacions sobre el tractament de la violència de gènere als programes informatius $i$ d'entreteniment als mitjans de comunicació [Recommendations about the treatment of gender violence in the information and entertainment programs of the media] (Associació de Dones Periodistes de Catalunya et al. 2004, apud Comas-d'Argemir 2014) has been published. Comas$\mathrm{d}^{\prime}$ Argemir (2014) argues that the change in the journalistic representation of IPF over the years is due to a shift in the way the crime is viewed, i.e., from a private problem to a social and public concern. Similarly, Ryan and colleagues (2006) analyzed the changes in the coverage of DV murders before and after the publication of a handbook on best practices by the Rhode Island Coalition against DV, one of the guidelines reviewed by Sutherland and colleagues (2016). Ryan and associates (2006) noticed significant changes in the journalistic coverage, such as the increase of identification of the murder as DV and the use of experts and advocates as sources in their news, therefore making thematic coverage much more common than it was prior to the existence of the handbook.

\section{Limitations and final considerations}

This study's main limitation was the reduced number of textual items analyzed due to the choice to solely include news articles that referred to current and recent cases of IPF. This allowed for a more focused and specific study, however, future research may benefit from also considering the portrayal of IPV in news items about attempted IPF. Since the failure to consummate the murder is likely not due to the perpetrator's will, those articles should be an interesting addiction to the analysis.

Concluding, the journalistic coverage of IPF in the Portuguese newspaper JN has evolved, presenting more thematic frames than episodic frames in 2014, 
and more thematic and less episodic frames in 2014 than in 2006. This contributes to the construction of femicide and IPV against women as social problems that need public attention and societal solutions. However, some episodic frames are still present, which propagate myths about IPV and IPF, and its perpetrators and victims. As demonstrated by the examples from Cataluña, Spain, and Rhode Island, USA, these frames might be eliminated in favor of a better representation of these issues with a closer work between journalists and experts, perhaps in the form of guidelines or a handbook that take into account the specific dynamics of these issues and the journalistic concerns in the newsroom.

\section{Bibliographical References}

Angélico, Rocio, Violeta Dikenstein, Sabrina Fischberg, and Florencia Maffeo. 2014. «El feminicidio y la violência de género en la prensa argentina: un análisis de voces, relatos y actores». Universitas Humanistica 78: 281-303. DOI: https:/ / doi.org/10.11144/Javeriana.UH78.fvgp

Azambuja, Mariana Ruwer, and Conceição Nogueira. 2010. «Qual a importância da violência contra mulheres na Revista Portuguesa de Saúde Pública?» Revista Portuguesa de Saúde Pública 28(1): 57-65. Available at http://www.scielo.mec.pt/pdf/rpsp/ v28n1/v28n1a07.pdf

Beddoe, Liz. 2013. «Violence and the media». In Understanding violence: Context and practice in the human services, edited by Annabel Taylor and Marie Connolly, 65-78. Chirstchurch, NZ: Canterbury University Press.

Berns, Nancy. 2001. «Degendering the problem and gendering the blame: Political Discourse on Women and Violence». Gender $\mathcal{E}$ Society 15(2): 262-281. DOI: https: / / doi.org/10.1177/089124301015002006

Bullock, Cathy Ferrand. 2008. «Official Sources Dominate Domestic Violence Reporting». Newspaper Research Journal 29(2): 6-22.

Bullock, Cathy Ferrand, and Jason Cubert. 2002. «Coverage of Domestic Violence Fatalities by Newspapers in Washington State». Journal of Interpersonal Violence 17(5): 475499. DOI: https:/ / doi.org/10.1177/ 0886260502017005001

Carlyle, Kellie E., Michael D. Slater, and Jennifer L. Chakroff. 2008. «Newspaper Coverage of Intimate Partner Violence: Skewing Representations of Risk». Journal of Communication 58(1): 168-186. DOI: https: / / doi.org/10.1111/j.1460-2466.2007.00379.x

Cerqueira, Carla Braga. 2008. «A Imprensa e a Perspectiva de Género. Quando elas são notícia no Dia Internacional da Mulher». (OBS*) Observatorio 2(2): 139-164. Available at http:/ / obs.obercom.pt/index.php/obs/article/view/101

Coimbra, Artemisa. 2007. "Crónicas de Mortes Anunciadas - Violência doméstica, imprensa e questões de género em articulação com a educação da cidadania». MA diss., University of Porto.

Comas-d'Argemir, Dolors. 2014. «News of partner femicides: The shift from private issue to public problem». European Journal of Communication 30(2): 121-136. DOI: https: / / doi.org/10.1177/0267323114544865

Dobash, R. Emerson, and Russell P. Dobash. 2001. «Domestic Violence: Sociological Perspectives». In International Encyclopedia of the Social \& Behavioral Sciences, 3830-3834. Elsevier Science. DOI: https: / / doi.org/10.1016/b0-08-043076-7 / 03935-8 
Elo, Satu, and Helvi Kyngäs. 2008. «The qualitative content analysis process». Journal of Advanced Nursing 62(1): 107-115. DOI: https:/ / doi.org/10.1111/j.1365-2648.2007.04569.x

Fairbairn, Jordan, and Myrna Dawson. 2013. «Canadian News Coverage of Intimate Partner Homicide: Analyzing Changes Over Time». Feminist Criminology 8(3): 147-176. DOI: https:/ / doi.org/10.1177/1557085113480824

Foucault, Michel. 1972. The Archaeology of Knowledge. Translated by A. M. Sheridan Smith. London: Routledge Classics.

Gallego Ayala, Juana. 2003. «Producción informativa y transmisión de estereotipos de género en la prensa diaria». Comunicación y Sociedad 16(2): 49-66. Available at http: / / www.unav.es/fcom/communication-society / es/resumen.php?art_id=99

Garcia-Moreno, Claudia, Henrica AFM Jansen, Mary Ellsberg, Lori Heise, and Charlotte H. Watts. 2006. «Prevalence of Intimate Partner Violence: findings from the WHO multi-country study on women's health and domestic violence». Lancet 368(9543): 1260-1269. DOI: https:/ / doi.org/10.1016/S0140-6736(06)69523-8

Gillespie, Lane Kirkland, Tara N. Richards, Eugena M. Givens, and M. Dwayne Smith. 2013. «Framing Deadly Domestic Violence: Why the Media's Spin Matters in Newspaper Coverage of Femicide». Violence Against Women 19(2): 222-245. DOI: https: / / doi.org/10.1177/1077801213476457

Gitlin, Todd. 1980. The whole world is watching. Berkeley: University of California Press.

Goffman, Erving. 1974. Frame analysis: An essay on the organization of experience. Boston: Northeastern University Press.

Graham, Linda J. 2005. «Discourse Analysis and the Critical Use of Foucault». In The Australian Association of Research in Education Annual Conference, 27th November-1st December 2005, Parramatta, Sydney. Available at http://eprints.qut.edu.au/2689/ [accessed 5.10.2016].

Lledó Cunill, Eulália. 2003. «Recomendaciones para el Tratamiento de la Violencia Contra las Mujeres en los Medios Informativos». In Medios de comunicación y violência contra las mujeres, coordinated by María del Mar Ramírez Alvarado, 217-226. Sevilla: Instituto Andaluz de la Mujer, Fundación Audiovisual de Andalucía.

López Díez, Pilar. 2002. «La representación de violencia masculina contra las mujeres en los medios de comunicación». In Realidad y representación de la violência, edited by Olga Barrios, 139-157. Salamanca: Ediciones Universidad Salamanca.

Mahoney, Patricia, Linda M. Williams, and Carolyn M. West. 2001. «Violence Against Women by Intimate Relationship Partners». In Sourcebook on Violence Against Women, edited by Claire M. Renzetti, Jeffrey L. Edleson, and Raquel Kennedy Bergen, 143178. Thousand Oaks, CA: SAGE.

Matheson, Donald. 2005. Media discourses: Analysing media texts. Maidenhead: Open University Press.

Reese, Stephen D. 2001. «A bridging model for media research». In Framing Public Life: Perspectives on Media and our Understanding of the Social World, edited by Stephen Reese, Oscar Gandy, and August Grant, 7-31. Mahwah, NJ: Lawrence Erlbaum.

Richards, Tara N., Lane Kirkland Gillespie, and M. Dwayne Smith. 2011. «Exploring News Coverage of Femicide: Does reporting the news add insult to injury?» Feminist Criminology 6(3): 178-202. DOI: https:/ / doi.org/10.1177/1557085111409919

Richards, Tara N., Lane Kirkland Gillespie, and M. Dwayne Smith. 2013. «An examination of the media portrayal of femicide-suicides: An exploratory frame analysis». Feminist Criminology 9(1): 24-44. DOI: https: / / doi.org/10.1177/1557085113501221

Richards, Tara N., Lane Kirkland Gillespie, and Eugena M. Givens. 2014. «Reporting Femicide-Suicide in the News: The Current Utilization of Suicide Reporting Guide- 
lines and Recommendations for the Future». Journal of Family Violence 29(4): 453-463. DOI: https: / / doi.org/10.1007/ s10896-014-9590-9

Russel, Diana E. H. 1992. «Preface to Femicide: The Politics of Woman Killing, edited by Jill Radford and Diane E. H. Russel, xi-xv. New York: Twayne.

Ryan, Charlotte, Mike Anastario, and Alfredo DaCunha. 2006. «Changing Coverage of Domestic Violence Murders: A Longitudinal Experiment in Participatory Communication». Journal of Interpersonal Violence 21(2): 209-228. DOI: https: / / doi.org/ $10.1177 / 0886260505282285$

Scheufele, Dietram A. 1999. «Framing as a Theory of Media Effects». Journal of Communication 49(1): 103-122. DOI: https: / / doi.org/10.1111/j.1460-2466.1999.tb02784.x

Simões, Rita Joana Basílio. 2011. «Crime, Castigo e Género nas Sociedades Mediatizadas: Políticas de (In)justiça no Discurso dos Media». PhD diss., Universidade de Coimbra.

Sutherland, Georgina Ann, Angus McCormack, Patricia L. Easteal, Kate Holland, and Jane Pirkis. 2016. «Media Guidelines for the Responsible Reporting of Violence Against Women: A Review of Evidence and Issues». Australian Journalism Review 38(1): 5-17.

Thornborrow, Joanna. 2004. "Language and the media». In Language, society and power, edited by Linda Thomas, Shân Wareing, Ishtla Singh, Jean Stilwell Peccei, Joanna Thornborrow, and Jason Jones, 55-79. Abingdon, Oxon: Routledge.

Valdemarca, Laura, and Bonavitta, Paola. 2011. «La violencia intrafamiliar como representación en la prensa gráfica en el diario de mayor distribución en el interior de Argentina». Revista de Estudios Sociales 39: 70-79. DOI: https: / / doi.org/10.7440/ res39.2011.06

Wilson, Margo, and Martin Daly. 1993. «An Evolutionary Psychological Perspective on Male Sexual Proprietariness and Violence Against Wives». Violence and Victims 8(3): 271-294.

Wozniak, Jessica A., and Kathy A. McCloskey. 2010. «Fact or fiction? Gender issues related to newspaper reports of intimate partner homicide». Violence Against Women 16(8): 934-952. DOI: https: / / doi.org/10.1177/1077801210375977

Carolina Magalhães-Dias. Degree in Criminology in 2015 from the Faculty of Law, University of Porto. Curricular internship conducted in UMAR (Union of Women and Alternative Response), with the participation in the P'RA TI, Call Centre for Female Victims of Violence, and on the projects of primary prevention of violence ArtWays and Art'themis. Attends master's degree in developmental psychology at the Faculty of Psychology and Educational Sciences, University of Coimbra.

Soraia Lobo. Degree in Criminology in 2015 at the Faculty of Law, University of Porto. Internship at Portuguese Association for Victim Support (APAV), where she completed the Basic Course of Service to Victims of Crime.

Article received on 15 April 2016 and accepted for publication on October 20, 2016. 